\title{
LONG-TERM ESTIMATION OF ACTUAL CROP EVAPOTRANSPIRATION BASED ON SATELLITE DATA ANALYSIS
}

\author{
Youssef ${ }^{1 *}$ M.A., Arafa ${ }^{1}$ Y.E., El-Gindy ${ }^{1}$ A.M. and El-Shirbeny ${ }^{2}$ M.A. \\ 1- Agric. Engineering. Dept., Fac. of Agric., Ain Shams Univ., P.O. Box 68, Hadayek \\ Shobra11241, Cairo, Egypt \\ 2- National Authority for Remote Sensing and Space Sciences, Egypt \\ *Corresponding author: mohamedabdou25893@gamil.com
}

Received 2 December, 2019

Accepted 26 December, 2019

\section{ABSTRACT}

Arid regions conditions are overwhelmed with various water scarcities problems, however, one of the reasons of this problems may be due to climate change effect. Moreover, under these conditions, water is a crucial key for any agricultural development processes. Therefore, the aim of this study was to estimate the actual evapotranspiration of different crop pattern under climate change conditions based on satellite data analysis for long time effect (1985 - 2019).

The study area is considered active agricultural area, the percentage of bare soil and vegetation cover were $(86.9 \%)$ and (12.7) in 1985 while in 2019 the percentage of bare soil sharply decrease so it was reached to $(34.1 \%)$ but the percentage of d vegetation cover was (64.2\%).

Satellite images have been gathered and analyzed from Landsat TM, Landsat ETM+ and Landsat OLI, through the studied period. However, Normalized Difference Vegetation Index (NDVI) had been obtained for estimating the actual evapotranspiration under the studied area conditions. Planning and management of water use by irrigation agriculture are especially important in an arid and semiarid areas like the study area so the understanding of the Actual Evapotranspiration (AET) prerequisite for better management and conservation of agriculture water, By determine the area of every crop pattern, actual evapotranspiration (AET) was estimated by $\mathrm{m}^{3} / \mathrm{ha} /$ day and $\mathrm{m}^{3} /$ total cultivated area/day.

Data analysis indicate that the minimum and maximum NDVI values had been ranged from 0.7 and 0.9 for mango trees from 1985 and 2019, 0.5 and 0.8 for olive trees, 0.4 and 0.8 for forests and 0.7 for annual crops within the studied period from
1985 to 2019. The minimum and maximum actual evapotranspiration under different crop pattern from 1985 to 2019 ranged from 2.6 and 4.9 $\mathrm{mm} /$ day, 1.7 and $4 \mathrm{~mm} /$ day, 1 to $4.4 \mathrm{~mm} /$ day and $2.7 \mathrm{~mm} /$ day for the same crop pattern respectively. This study can assist in water management practices for better irrigation management.

Keywords: Reference Evapotranspiration (ETo), Crop Coefficient $\left(\mathrm{K}_{\mathrm{c}}\right)$, Remote Sensing (RS) and land Surface Temperature (LST).

\section{INTRODUCTION}

Agricultural sectors are facing many environmental challenges, such climate change and reduction of water resource. Agricultural water use and cropping patterns are closely related to each other, with both linked to the regional climate (Daliakopoulos et al 2017). Remote sensing has been beneficial tool for water resources management studding, especially when we look at regional scale. Planning and management of water use by irrigation agriculture are especially important in an arid and semiarid areas like the study area so the understanding of the Actual Evapotranspiration (AET) prerequisite for better management and conservation of agriculture water (Agdasi, 2010).

Normalized Difference Vegetation Indix (NDVI) is the main vegetation indices. NDVI considers the reflected wavebands in red and near-infrared, where red wave band is substantially absorbed by chlorophyll in the top layers of leaves, nevertheless near-infrared wave bands are reflected by the mesophyll structure in leaves in the healthy and density vegetation (Romero Trigueros et al 2017). High values of NDVI are considered as healthy and density vegetation, which presents 
rising reflectance values in NIR waveband and depressed reflectance values in the red waveband (Toureiro et al 2017).

Estimation of $\mathrm{K}_{\mathrm{c}}$ based on NDVI on account of the high correlation NDVI with $\mathrm{K}_{\mathrm{c}}$ (Abuzar et al 2013, Campos et al 2017, Reyes-González et al 2018, Mahmoud and Gan 2019). Because of this high relationship between NDVI and $\mathrm{K}_{\mathrm{c}}$, NDVI has been broadly used for vegetation monitoring, crop yield estimating and drought detection (Justice and Townshend 2002). Crop coefficients created from vegetation indices to determine $\mathrm{ET}_{\mathrm{c}}$ was realistic than a tabulated $\mathrm{Kc}$ because it represents the actual crop developing conditions and capture the spatial variability within different fields (ReyesGonzalez et al 2018). Estimation of ET can be the basic process to determine (ACWR) (Hasan et al 2018). basically, ET has been difficult and costly to estimate (Rozenstein et al 2018). $\mathrm{ET}_{\mathrm{c}}$ can estimated at macro / micro scale in less time by utilizing remote sensing (Kjaersgaard et al 2011).

In this study satellite remote sensing (RS) will be used to quantify Actual Evapotranspiration $(A E T)$, which plays a key role in the conservation and management of water resources.

\section{Materials and Methods}

\subsection{Description of the studied area}

The study area is located at $32^{\circ} 10^{\prime} 58.46 " E$ to $32^{\circ} 18^{\prime} 31.784 " \mathrm{E}$ longitude and $30^{\circ} 26^{\prime} 32.11^{\prime \prime} \mathrm{N}$ to $30^{\circ} 31^{\prime} 8.204 " \mathrm{~N}$ latitude in the Northern East of Egypt, the distance between the east border of the study area and the Suez Canal is $2.25 \mathrm{~km}$ at the North and $4 \mathrm{~km}$ at the south. The study area covers approximately $102.6 \mathrm{~km}^{2}$ (10260 ha) illustrated in (Fig. 1A). The vegetation cover area increased from 1299.2 ha (12.7\%) in 1985 to 6591.5 ha $(64.2 \%)$ in 2019 see (Table 1) and (Fig. 1B). The study area is considered active agricultural area and were selected because of the rapid increase in cultivated area during the past few years which make it good area for monitoring, mapping and analyzing the interaction dynamic between vegetation and climate change.

The mean annual maximum temperature is $29.1^{\circ} \mathrm{C}$, minimum $15.3^{\circ} \mathrm{C}$ and mean $21.7^{\circ} \mathrm{C}$. The mean annual relative humidity is about $48.8 \%$, mean annual solar radiation is $19.8\left(\mathrm{MJ} / \mathrm{m}^{2} /\right.$ day $)$ and the mean annual wind speed is $3.5(\mathrm{~m} / \mathrm{s})$ and
The average ETo is 5.9 ( $\mathrm{mm} /$ day) for duration of 33 years (1985 to 2017) Mean elevation from Sea surface is $3 \mathrm{~m}$ to $86 \mathrm{~m}$.

The crop patterns in the study area divided into three categories showed in (Fig. 1A), the first one is orchard such as mango and olive trees. Mango trees located north east part and irrigated with surface water by surface irrigation system. Parallel with the north west part that were majority cultivated with olive trees, but these trees irrigated with aquifer wells. The second category are forest that located in the middle of study area approximately and irrigated with treated sewage water since 1997 by surface drip irrigation system. The third category are crops that located in the south part of the study area. Its cultivated under center pivots irrigation system and the water source from aquifer since 2016.

Based on GPS tool lot of point were observed and recorded. (Fig. 1A) illustrated the important points of these records. Point (1) show the parts that majority cultivated with mango trees. Point (2) display the site that cultivated with olive trees. Point (3) illustrate the area that cultivated with combination of trees such as mango, olive and orange. Point (4) show the Serapeum forest that cultivated with wooden trees, Point (5) illustrated the part that cultivated under center pivots. Point (6), Ismailia sewage water were collected and treatment in this part after that utilized these treatment water to irrigate the Serapeum forest. Point (7) show the surface water that infiltrated from Suez Canal.

\subsection{Initial data sources}

\subsubsection{Meteorological data}

Meteorological data were directly recorded from the available weather station that located at $31^{\circ} 57^{\prime} 39.6^{\prime \prime}$ longtude, $30^{\circ} 31^{\prime} 37.2^{\prime \prime}$ latitude and that belong to Central Laboratory for Agriculture Climate (CLAC). The distance between study area and that station about $21.5 \mathrm{~km}$ distance this distance is not significant according to (EL- Shirbeny et al 2013). The reference evapotranspiration (ETo) calculated by ETo calculator version 3.2. ETo calculator is software developed by FAO. The prime function of this calculator is to estimate ETo based on FAO standards (Zahid and Rasul, 2011). Result in (Fig. 2) indicate that the maximum. 
Table 1. The crop pattern percent

\begin{tabular}{|c|c|c|c|c|c|c|c|c|}
\hline Year & $\mathbf{1 9 8 5}$ & $\mathbf{1 9 9 0}$ & $\mathbf{1 9 9 5}$ & $\mathbf{2 0 0 0}$ & $\mathbf{2 0 0 5}$ & $\mathbf{2 0 1 0}$ & $\mathbf{2 0 1 5}$ & $\mathbf{2 0 1 9}$ \\
Crop pattern & & & & & & \\
\hline Orchard trees & $12.9 \%$ & $19.3 \%$ & $22.0 \%$ & $38.1 \%$ & $41.3 \%$ & $46.5 \%$ & $49.8 \%$ & $56.9 \%$ \\
Forest trees & $0 \%$ & $0 \%$ & $0 \%$ & $0.2 \%$ & $1.6 \%$ & $1.6 \%$ & $1.6 \%$ & $1.6 \%$ \\
Annual crops & $0 \%$ & $0 \%$ & $0 \%$ & $0 \%$ & $0 \%$ & $0 \%$ & $0 \%$ & $5.8 \%$ \\
\hline
\end{tabular}
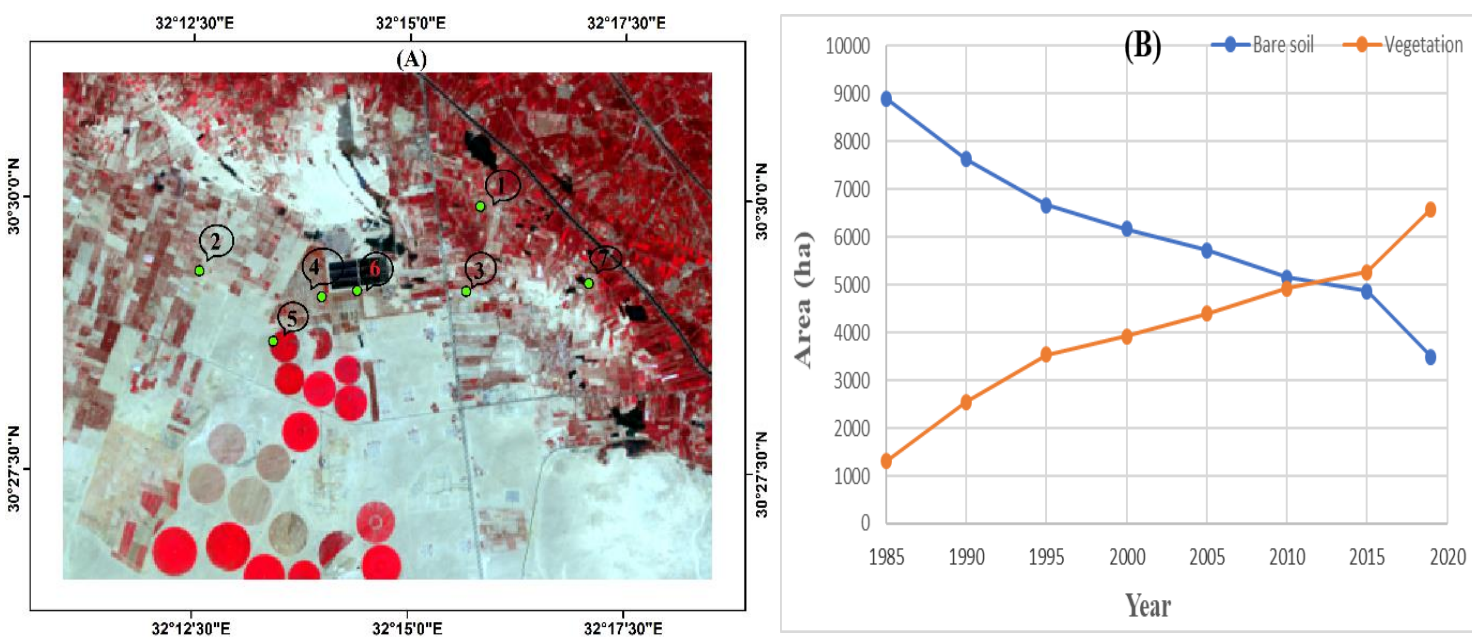

Fig. 1. (A) Location of the study area, (B) Accumulative analysis of agricultural development processes versus bare soils within the studied period.

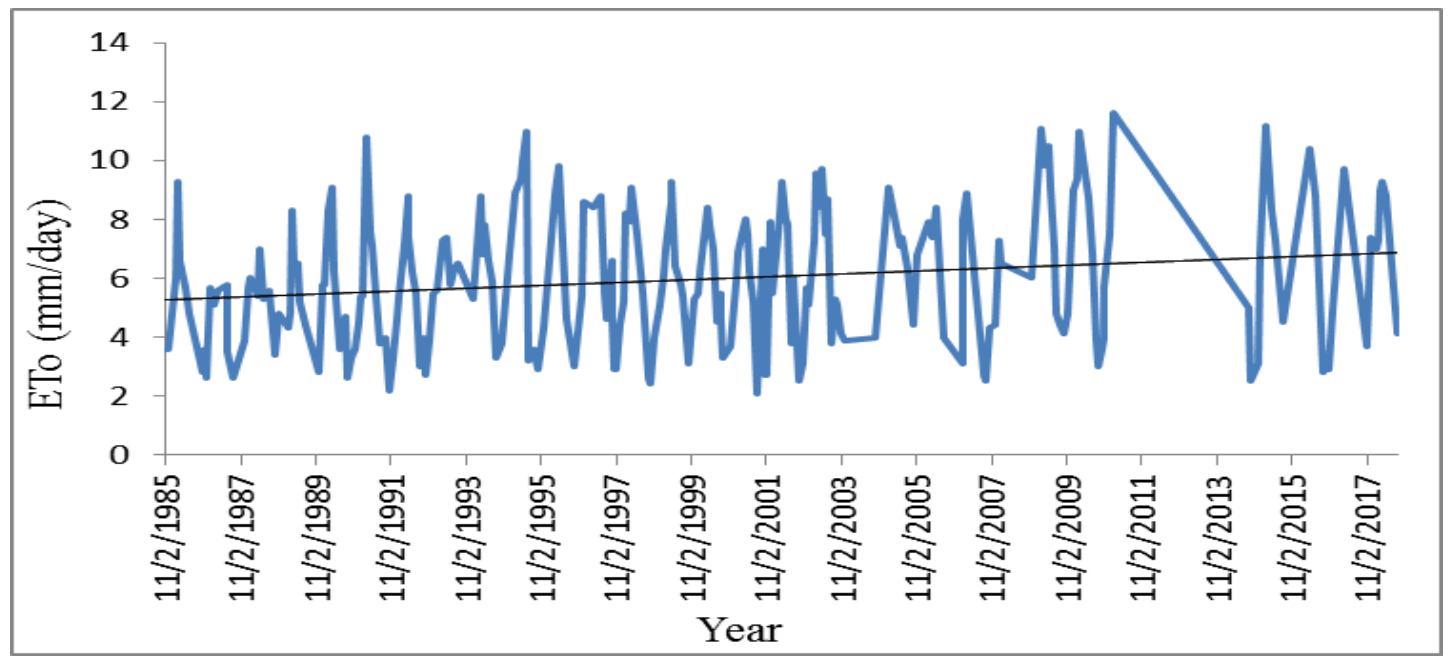

Fig. 2. ETo (mm/day) values from 1985 to 2017

AUJASCI, Arab Univ. J. Agric. Sci., 27(5), 2019 


\subsubsection{Satellite data gathering and processing}

Data from remote sensing were the primary input data in study. The satellite data sets were downloaded for the Landsat satellite. These images were gained from the [USGS] website (http://earthexplorer.usgs.gov/) from the year 1985 to 2019. The data processing for TM, ETM+ \& OLI data mainly includes radiometric correction and atmospheric correction. All utilized images were free cloud during image acquisition. All images processing steps were performed utilizing ENVI software 5.1 .

A combination of Landsat-5 Thematic Mapper (TM), Landsat-7 (ETM+) and Landsat-8 (OLI) imagery were employed in study. Landsat 5 is the most important satellite for this study because of utilizing 200 images from it from 1985 to 2010, In 13 images utilized from Landsat 7 from 2001 to 2003 only because the problem in this sensor and Utilized 25 images from Landsat 8, 23 images from the period 2013 to 2017 and two imaged in 2019. All data registered into UTM projection system (UTM-WGS84) and zone 36, north. The details of satellites data are showed at (Table 2).

\subsection{Data analysis and calculations}

\subsubsection{Normalized Difference Vegetation Index (NDVI)}

NDVI was introduced by (Rouse et al 1973) to monitor the vegetation using satellite images, it takes into account the reflectance of red $(0.61$ $0.68 \mu \mathrm{m})$ and near infrared NIR (0.79 - $0.89 \mu \mathrm{m})$ wavebands and was computed as the ratio of target radiance to time interpolated values of solar radiance. NDVI is calculated from the Red and NIR bands from TM, ETM+ and OLI images using the following Equation.

$$
\text { NDVI }=\frac{(\mathbf{N I R}-\mathrm{R})}{(\mathrm{NIR}+\mathrm{R})}
$$

Where, NIR and Red are the spectral reflectance red and near-infrared bands in the TM, ETM+ and OLI. Estimation of NDVI for a given pixel evermore valid results fall between ranges from -1 to +1 ; where positive values signify more green vegetation and negative values indicate non vegetated surface features.

\subsubsection{Crop coefficient ( $\left.K_{c ~ s a t}\right)$}

$\mathrm{K}_{\mathrm{c}}$ is approximately between 0.1 and 1.2. Relation between $\mathrm{K}_{\mathrm{c}}$ sat and NDVI performed by following Equation which established by (El-Shirbeny., et al 2014).

$$
\mathrm{Kc}_{\mathrm{sat}}=\frac{1.2}{\mathrm{NDVI}_{\mathrm{dv}}}\left(\mathrm{NDVI}-\mathrm{NDVI}_{\min }\right)
$$

Where 1.2 presented the maximum $\mathrm{K}_{\mathrm{c}}$ under Egyptian conditions, $\mathrm{NDVI}_{\mathrm{dv}}$ is the difference maximum and minimum NDVI values for vegetation and $\mathrm{NDVI}_{\text {min }}$ is the minimum NDVI value for vegetation.

\subsubsection{Crop Evapotranspiration $\left(E T_{c}\right)$}

$\mathrm{K}_{\mathrm{c} \text { sat }}$ utilized with $\mathrm{ET}_{\mathrm{o}}$ to estimate $\mathrm{ET}_{\mathrm{c}}$ according tofollowing Equation.

$$
E T_{c}=E T_{0}{ }^{*} K_{c} \text { sat }
$$

Where; $E T_{c}$ is crop evapotranspiration (mm/day), $E T_{0}$ is reference evapotranspiration $\left(\mathrm{mm} /\right.$ day), $\mathrm{K}_{\mathrm{c}}$ sat is crop coefficient by satellite data. Based on the area of every crop pattern actual evapotranspiration (AET) was estimated by $\mathrm{m}^{3} /$ ha/day and $\mathrm{m}^{3} /$ total cultivated area/day.

\subsubsection{Land Surface Temperature (LST)}

For Landsat data, the recorded digital numbers (DN) were transformed to radiance units (Rad) utilizing the calibration coefficient certain for each band.

Radiance $=$ Gain ${ }^{\star}$ DN+ offset

Surface emissivity (Eo) generated from the NDVI. NDVI utilizing the empirical equation that developed from row data on thermal emissivity and NDVI thermal emissivity according to (Valor and Caselles, 1996).

$$
\text { Eo }=0.9932+0.0194 \ln N D V I
$$

The radiant temperature (To) can be calculated from band 6, 6.1 and 10 (Rad) based on (Goetz et al 1995), however the thermal Band Calibration Constants could be described as Table (2).

$$
\begin{array}{lr}
\text { To }=K 2 / \ln ((\mathrm{K} 1 / \operatorname{Rad} 6)+1) & \text { Landsat } 5(6 a) \\
\text { To }=\mathrm{K} 2 / \ln ((\mathrm{K} 1 / \operatorname{Rad} 6.1)+1) & \text { Landsat } 7(6 \mathrm{~b}) \\
\text { To }=\mathrm{K} 2 / \ln ((\mathrm{K} 1 / \operatorname{Rad} 10)+1) & \text { Landsat } 8(6 \mathrm{c})
\end{array}
$$


Table 2. Technical specification of satellites

\begin{tabular}{|c|c|c|c|c|c|}
\hline Sensors & Path/Row & Bands & K1 $\left(\mathbf{W m}^{-\mathbf{2}} \mathbf{s r}^{-1} \mathbf{\mu m}^{-1}\right)$ & $\mathbf{K 2}$ (Kelvin) & Source \\
\hline Landsat 5 TM & $176 / 39$ & 3,4 & 1260.56 & 607.76 & earthexplorer.usgs.gov \\
& & 6 & & & \\
Landsat 7 ETM+ & $176 / 39$ & 3,4 & 1282.71 & 666.09 & earthexplorer.usgs.gov \\
& & 6.1 & & 774.89 & earthexplorer.usgs.gov \\
Landsat 8 OLI & $176 / 39$ & 4,5 & 1321.08 & & \\
& & 10 & & &
\end{tabular}

The effects of atmospheric and emissivity of thermal surface have to be count for reach the accurate surface temperature data from satellite thermal (Norman et al 1995). The surface temperature was studied from the top of atmosphere radiant temperature (To) and estimated surface emissivity (Eo) as:

$$
\mathbf{T}=\text { To/Eo }
$$

The temperature in Kelvin were converted to Celsius degrees using the following Equation

$$
\operatorname{LST}\left({ }^{\circ} \mathrm{C}\right)=\mathrm{T}-273.13
$$

\subsubsection{Predicted Crop Evapotranspiration $\left(E T_{c}\right)$}

Either LST and NDVI indices had been combined with metrological parameters data for estimating the actual evapotranspiration of different crops pattern of the studied area.

\section{Result and Discussion}

The study area divided into three category of crop pattern, NDVI and ETc were estimated under mango, olive, forest and annual crops. By determine the area of every crop pattern, actual evapotranspiration (AET) was estimated by $\mathrm{m}^{3} / \mathrm{ha} /$ day and $\mathrm{m}^{3} /$ ha/total cultivated area. Result in (Table 3) illustrated the NDVI and ETc under different crop pattern from 1985 to 2019. The number of zero demonstrated that this crop pattern not cultivated in this year. Result in (Table 4) indicate the actual evapotranspiration (AET) $\mathrm{m}^{3} / \mathrm{ha} /$ day and total actual evapotranspiration $\mathrm{m}^{3} /$ cultivated area/day under different crop pattern from 1985 to 2019. The number of zero demonstrated that this crop pattern not cultivated in this year.

\subsection{Data analysis of observed NDVI}

Data analysis of the NDVI indicate that NDVI values had been high significant increase. The NDVI increasing due to plant density and vegetation area, as presented in (Fig. 4). According to cultivation a new region under center pivots, its affected that on NDVI values, so the NDVI values were sharply increasing. Data analysis indicate that the NDVI values had been ranged from 0.7 up to 0.9 for mango trees, 0.5 to 0.8 for olive trees, 0.4 up to 0.8 for forests and 0.7 for annual crops within the studied period. The NDVI values under different crop pattern showed in (Table 3).

\subsection{Data analysis of observed $\mathrm{K}_{\mathrm{c} \text { sat }}$}

$\mathrm{K}_{\mathrm{c}}$ dependence on crop pattern was estimated based on satellite data. $\mathrm{K}_{\mathrm{c}}$ values utilized to estimate actual evapotranspiration.

\subsection{Actual Evapotranspiration}

Data analysis in (Fig. 4) presents $E T_{c}$ maps (mm/day) on $\left(11^{\text {th }}\right.$ Feb $1985,24^{\text {th }}$ Jan $1990,06^{\text {th }}$ Jan $1995,19^{\text {th }}$ Nov $2000,01^{\text {st }}$ Nov $2005,15^{\text {th }}$ Jan 2010, 15 $5^{\text {th }}$ Dec 2015 and 25 th Feb 2019). These images were selected to be an indicator of minimum mean $E T_{c}$. The range of $E T_{c}$ is divided from (0: $5 \mathrm{~mm} /$ day). It is better to assessment the vegetation covers every 5 years to monitor changing in cultivated areas which affects the agricultural sector especially in arid and semi-arid regions. 
Table 3. NDVI, $\mathrm{K}_{\mathrm{c} \text { sat }}$ and $\mathrm{ET}_{\mathrm{c}}$ under different crop pattern

\begin{tabular}{|c|c|c|c|c|c|c|c|c|}
\hline \multirow{2}{*}{ Years Crop pattern } & \multicolumn{2}{|c|}{ Mango trees } & \multicolumn{2}{c|}{ Olive trees } & \multicolumn{2}{c|}{ Forest trees } & \multicolumn{2}{c|}{ Annual crops } \\
\cline { 2 - 9 } & NDVI & $\mathbf{E T}_{\mathbf{c}}$ & NDVI & $\mathbf{E T}_{\mathbf{c}}$ & NDVI & ET $_{\mathbf{c}}$ & NDVI & ET $_{\mathbf{c}}$ \\
\hline $\mathbf{1 9 8 5}$ & 0.7 & 3.1 & 0.5 & 2.4 & 0 & 0 & 0 & 0 \\
$\mathbf{1 9 9 0}$ & 0.7 & 2.6 & 0.6 & 2.0 & 0 & 0 & 0 & 0 \\
$\mathbf{1 9 9 5}$ & 0.7 & 2.7 & 0.5 & 1.7 & 0 & 0 & 0 & 0 \\
$\mathbf{2 0 0 0}$ & 0.7 & 3.1 & 0.7 & 2.9 & 0.4 & 1.0 & 0 & 0 \\
$\mathbf{2 0 0 5}$ & 0.7 & 4.9 & 0.6 & 4.0 & 0.7 & 4.4 & 0 & 0 \\
$\mathbf{2 0 1 0}$ & 0.7 & 4.7 & 0.6 & 3.0 & 0.6 & 3.6 & 0 & 0 \\
$\mathbf{2 0 1 5}$ & 0.8 & 3.1 & 0.8 & 2.5 & 0.8 & 3.2 & 0 & 0 \\
$\mathbf{2 0 1 9}$ & 0.9 & 3.5 & 0.7 & 2.2 & 0.6 & 2.5 & 0.7 & 2.7 \\
\hline
\end{tabular}

Table 4. Actual crop water requirements per ha and all crop pattern cultivated area

\begin{tabular}{|c|c|c|c|c|c|c|c|c|c|}
\hline \multirow[b]{2}{*}{ Year } & \multicolumn{3}{|c|}{ Orchard trees } & \multicolumn{3}{|c|}{ Forest } & \multicolumn{3}{|c|}{ Crops } \\
\hline & $\begin{array}{c}\text { AET } \\
\mathrm{m}^{3} / \mathrm{ha} \\
\text { /day }\end{array}$ & $\begin{array}{c}\text { Area } \\
\text { (ha) }\end{array}$ & $\begin{array}{c}\text { TAET } \\
\mathrm{m}^{3} / \\
\text { cultivated } \\
\text { area/ day }\end{array}$ & $\begin{array}{c}\text { AET } \\
\mathrm{m}^{3} / \mathrm{ha} \\
/ \text { day }\end{array}$ & $\begin{array}{c}\text { Area } \\
\text { (ha) }\end{array}$ & $\begin{array}{c}\text { TAET } \\
\mathrm{m}^{3} / \\
\text { cultivated } \\
\text { area/ day }\end{array}$ & $\begin{array}{c}\text { AET } \\
\mathrm{m}^{3} / \mathrm{ha} \\
\text { /day }\end{array}$ & $\begin{array}{c}\text { Area } \\
\text { (ha) }\end{array}$ & $\begin{array}{c}\text { TAET } \\
\mathrm{m}^{3} / \\
\text { cultivated } \\
\text { area/ day }\end{array}$ \\
\hline 1985 & 27.5 & 1299 & 35723 & 0 & 0 & 0 & 0 & 0 & 0 \\
\hline 1990 & 23 & 2557 & 58811 & 0 & 0 & 0 & 0 & 0 & 0 \\
\hline 1995 & 22 & 3538 & 77836 & 0 & 0 & 0 & 0 & 0 & 0 \\
\hline 2000 & 30 & 3905 & 117150 & 10 & 25 & 250 & 0 & 0 & 0 \\
\hline 2005 & 44.5 & 4237 & 188547 & 44 & 162 & 7128 & 0 & 0 & 0 \\
\hline 2010 & 38.5 & 4768 & 183568 & 36 & 162 & 5832 & 0 & 0 & 0 \\
\hline 2015 & 28 & 5112 & 143136 & 32 & 162 & 5184 & 0 & 0 & 0 \\
\hline 2019 & 28.5 & 5840 & 166440 & 25 & 162 & 4050 & 27 & 590 & 15930 \\
\hline
\end{tabular}

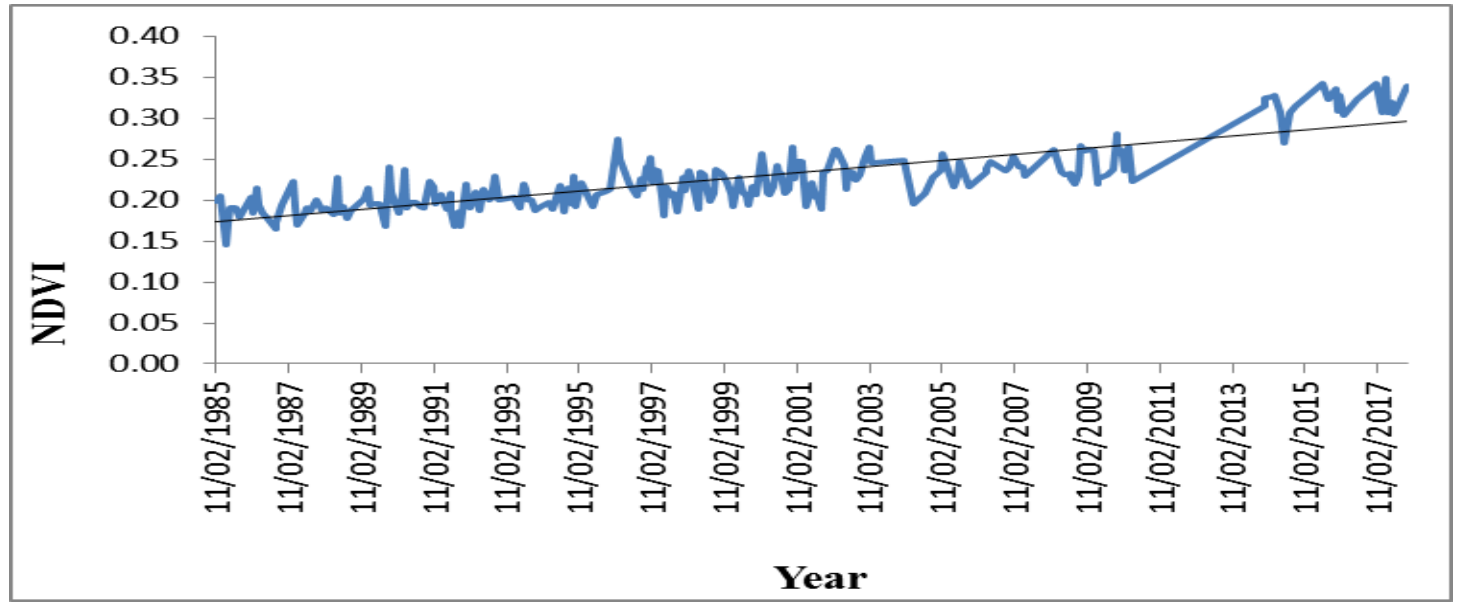

Fig. 3. Mean NDVI values during the period (1985 - 2017) 

on Satellite Data Analysis
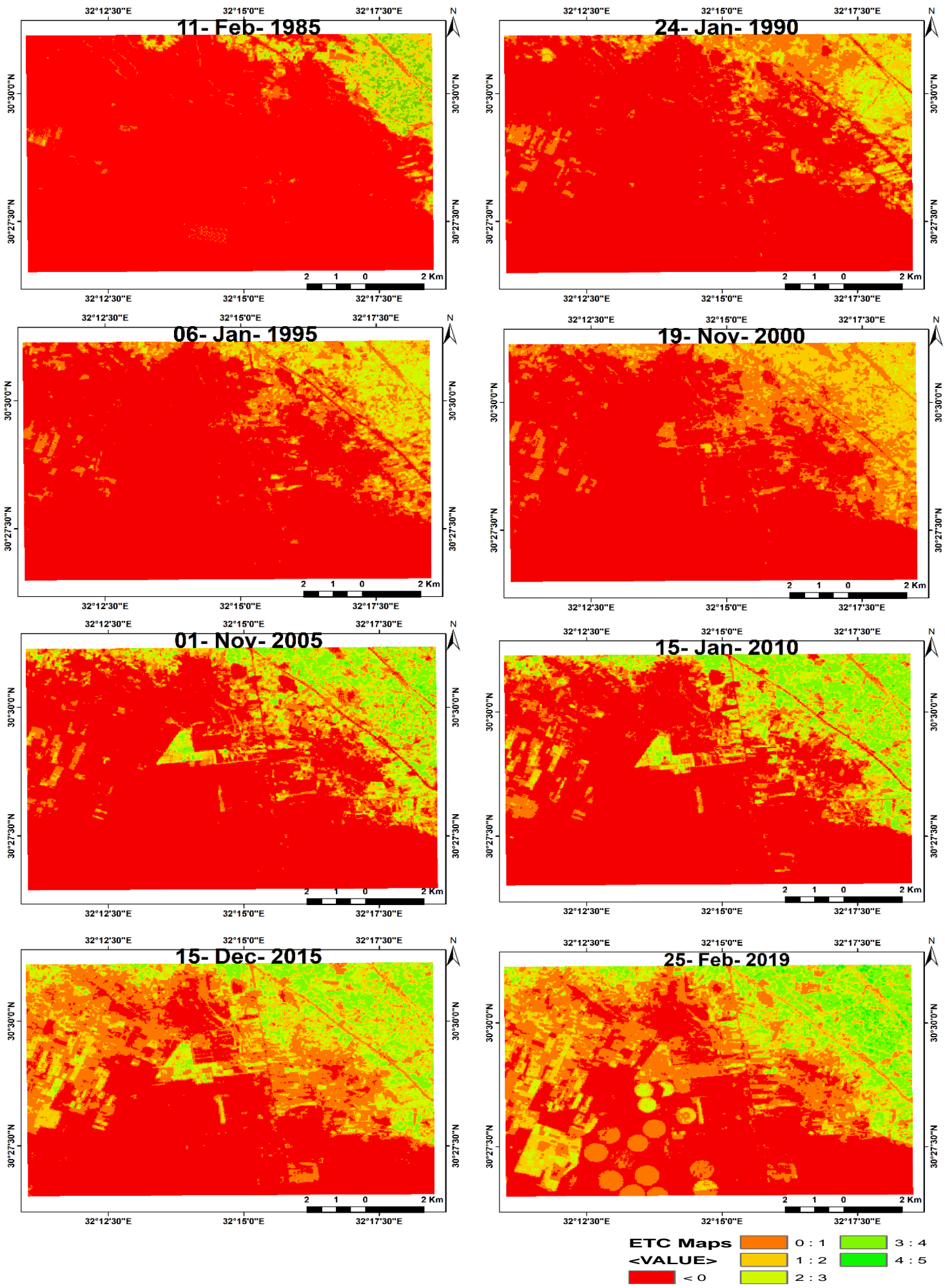

Fig. 4. Minimum mean of ETc maps (mm/day) for study area on $\left(11^{\text {th }}\right.$ Feb $1985,24^{\text {th }}$ Jan $1990,06^{\text {th }}$ Jan. $1995,19^{\text {th }}$ Nov. 2000, 01 ${ }^{\text {st }}$ Nov. 2005, $15^{\text {th }}$ Jan. 2010, $15^{\text {th }}$ Dec. 2015 and $25^{\text {th }}$ Feb. 2019). 
The $\mathrm{ET}_{\mathrm{c}}$ values were low at the beginning of cultivating area regarding to the cause of low $\mathrm{K}_{\mathrm{c}}$ after that the results show increasing in values of $\mathrm{ET}_{\mathrm{c}}$. The case study work on 239 images there are clear from clouds from 1985 up to 2019. According to $E T_{c}$ values that estimated from all available images, after that selected the minimum values in investigated years (1985, 1990, 1995, 2000, 2005, 2010, 2015 and 2019). Regardless about month. The maps illustrated that the $\mathrm{ET}_{\mathrm{c}}$ values were increased with time and with rising in vegetation cover. With comparison $(2005,2010$, 2015 and 2019) the $\mathrm{ET}_{\mathrm{c}}$ values under forest regions approximately stabled. Moreover, $\mathrm{ET}_{\mathrm{c}}$ values under center pivots variation between center pivots.

$\mathrm{ET}_{\mathrm{c}}$ maps $(\mathrm{mm} / \mathrm{day})$ on $\left(05^{\text {th }} \mathrm{Jul} 1985,19^{\text {th }} \mathrm{Jul}\right.$ 1990, $2^{\text {nd }}$ Aug 1995, $22^{\text {nd }}$ Jul 2000, $13^{\text {th }}$ Aug 2005, $07^{\text {th }}$ Jul 2010, 09th Aug 2015 and 04 ${ }^{\text {th }}$ Aug 2019) presented in (Fig. 5). These images were selected to be an indicator of maximum mean $E T_{c}$. The range of $E T_{c}$ is divided from $(0: 10 \mathrm{~mm} /$ day). According to $\mathrm{ET}_{\mathrm{c}}$ values that estimated from all available images, after that selected the maximum values in investigated years $(1985,1990,1995,2000$, 2005, 2010, 2015 and 2019). In 1985 and 1990, the $\mathrm{ET}_{\mathrm{c}}$ was depressed because the trees in forest was small and the vegetation cover per pixel was lower. After that the vegetation cover became high so the $\mathrm{ET}_{\mathrm{C}}$ was raised according to both pixel and all study area. The mean $\mathrm{ET}_{\mathrm{c}}$ of crop pattern were illustrated in (Table 3).

\subsection{Actual Evapotranspiration (AET)}

The data that illustrated in (Table 4) indicate the AET in the study area under different crop pattern the smallest AET under orchard trees (mango and olive) was $22 \mathrm{~m}^{3} /$ ha/day in 1995 largest AET was recorded in 2005 by $44.5 \mathrm{~m}^{3} / \mathrm{ha}$. Regardless, forest was recorded lowest AET by $10 \mathrm{~m}^{3} / \mathrm{ha}$ in 2019 and the largest AET was $44 \mathrm{~m}^{3} / \mathrm{ha} /$ day in
2005. On the other hand, AET under annual crops was $27 \mathrm{~m}^{3} / \mathrm{ha} /$ day. Based on the area of every crop pattern total actual evapotranspiration was estimated. 166440, 4050 and $15930 \mathrm{~m}^{3} /$ day for orchard trees, forest trees and annual crops.

\subsection{LST and mean air temperature (T mean)}

LST is an essential parameter of land surface energy budget and climate systems to monitor long-term environmental changes. The result in (Fig. 6) demonstrated that were decrease in LST and $\mathrm{T}$ mean $\left(-0.5^{\circ} \mathrm{C}\right.$ and $\left.-1.2^{\circ} \mathrm{C}\right)$ respectively through the period of study but this decreasing is insignificant at $5 \%$.

\subsection{Practical equation for estimation crop evapotranspiration $\left(E T_{c}\right)$}

Under the investigated study estimated $\mathrm{ET}_{\mathrm{c}}$ not to specific crop or tree but under crop patterns, so we need equation we can used it when it's difficult to determine the crop cultivated. So, calculated $E T_{c}$ values from this equation could obtained regardless the cultivated plant. To predicted $E T_{c}$, calculated $E T_{c}$ by following equation. By using 2015, 2016 and 2017 data to validate ET c, statistical analysis of RMSE used to insure of predicted $E T_{\text {c. }}$ The regression factors $R^{2}=0.80$ and RMSE is $0.6 \mathrm{~mm} /$ day that is showed in (Fig. 7).

ETc $=-1.256+\left(0.484^{\star}\right.$ ETo $)-\left(0.004^{\star}\right.$ LST $)+$ $\left(7.193^{\star} \mathrm{NDVI}\right)-\left(0.042^{\star} \mathrm{T}\right.$ mean $)-\left(0.006^{\star} \mathrm{SR}\right)+$ (0.002* RH) - (0.019*WS)

ETc: Crop Evapotranspiration [mm/day]. ETo: Reference Evapotranspiration [mm/day]. LST: Land Surface Temperature $\left[{ }^{\circ} \mathrm{c}\right]$. NDVI: Normalized Deference Vegetation Index. $\mathrm{T}$ mean: Mean air temperature $\left[{ }^{\circ} \mathrm{C}\right]$. SR: Solar radiation $\left[\mathrm{MJ} / \mathrm{m}^{\wedge} 2 /\right.$ day].

$\mathrm{RH}$ : Relative humidity [\%]. WS: Wind speed [m/s]. 

on Satellite Data Analysis
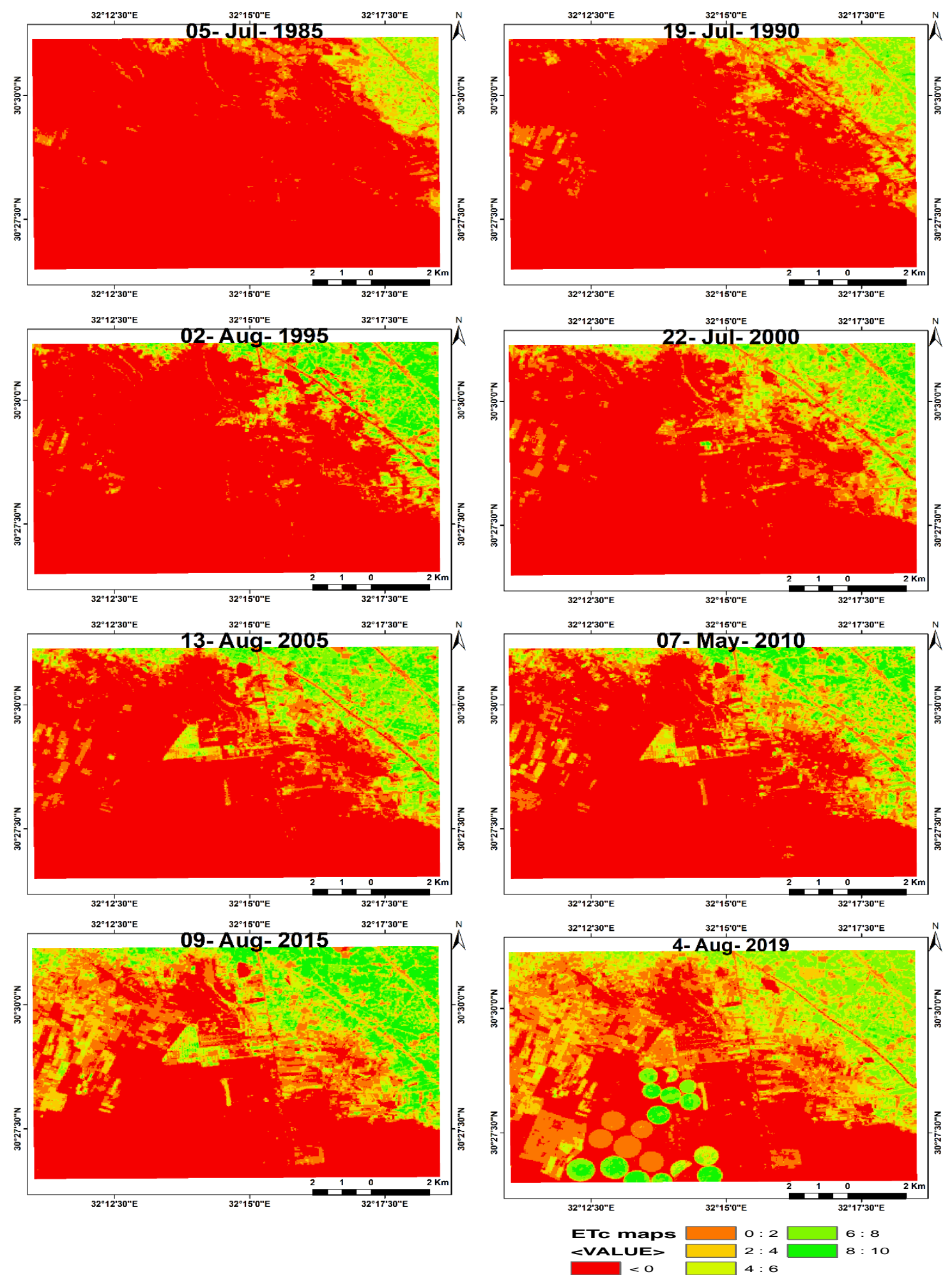

Fig. 5. Maximum mean of ETc maps (mm/day) for study area on (05

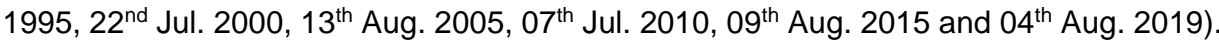




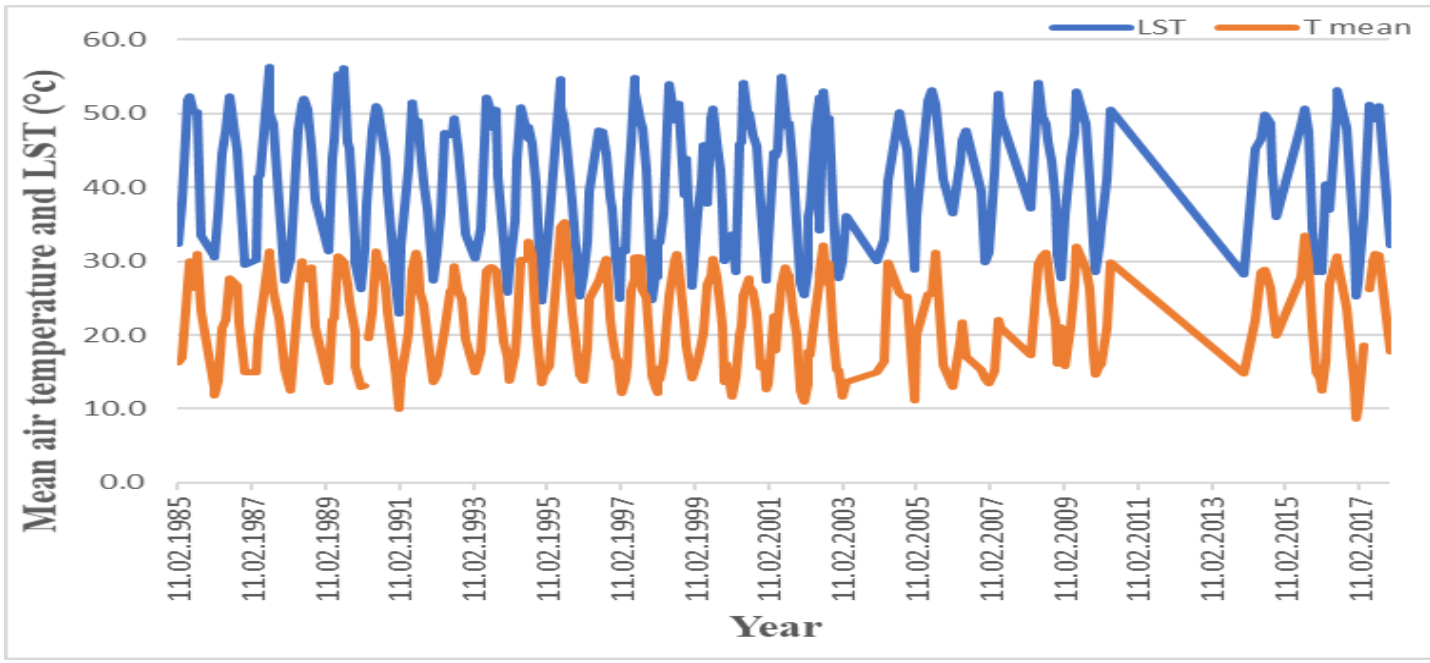

Fig. 6. LST and mean air temperature $\left({ }^{\circ} \mathrm{C}\right)$ from 1985 to 2017

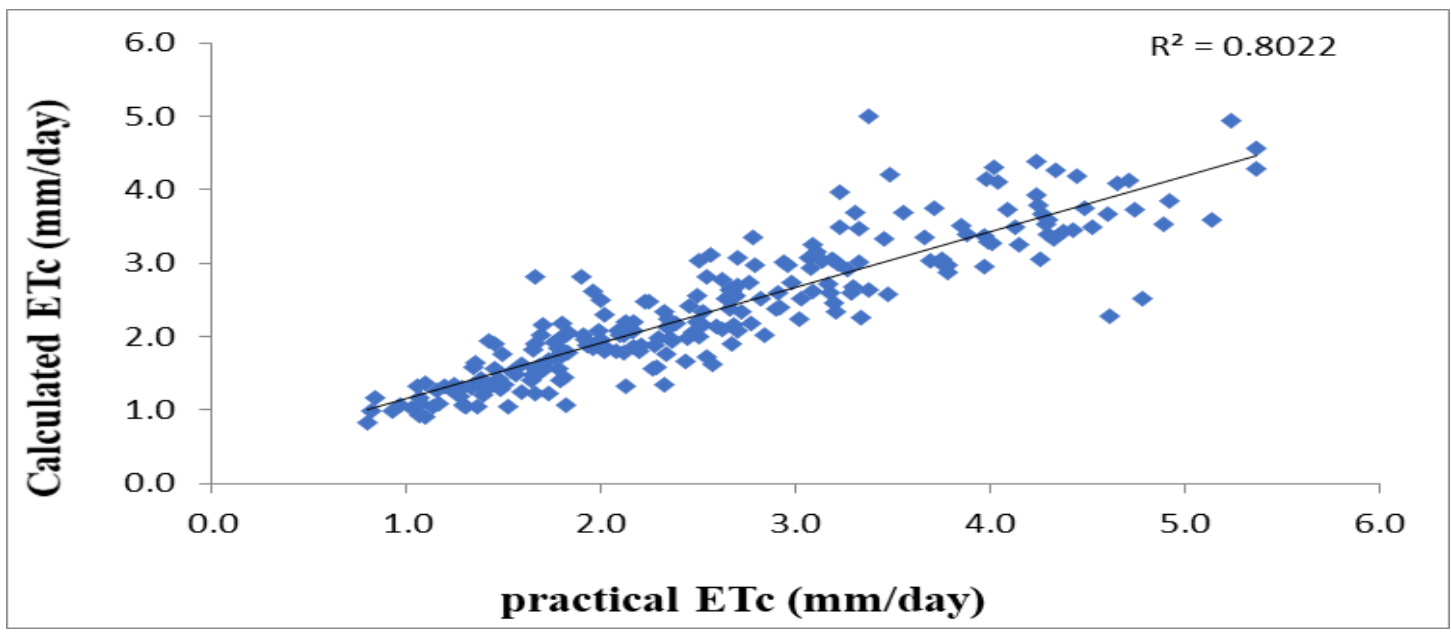

Fig. 7. Practical ETc (mm/day)

\section{CONCLUSION}

This study confirms the usefulness of utilizing remote sensing as a tool for actual crop evapotranspiration estimation. Landsat 5, 7 and 8 utilized to estimate NDVI under different crop pattern. $\mathrm{K}_{\mathrm{c} \text { sat }}$ $=\left(1.7{ }^{*} \mathrm{NDVI}-0.2\right)$ represent the relation between $\mathrm{K}_{\mathrm{c}}$ and NDVI. ET。 was calculated from $\mathrm{ET}_{\mathrm{o}}$ calculator software based on the Penman-Montieth formula. $K_{c}$ sat and ETo utilized to estimate actual crop evapotranspiration. Metrological data, ETo and LST used to predicted $E T_{c}$. Actual crop evapotraspiration were estimated under different crop pattern. Based on the results concluded that $E T_{c}$ estimated from remote sensed based on vegetation indices are a useful method for quantifying accurate $E T_{c}$ at macro / micro scales.

\section{REFERENCES}

Abuzar M., Whitfield D., McAllister A., Lamb G., Sheffield K., and O'Connell M. 2013. Satellite remote sensing of crop water use in an irrigation area of south-east Australia. IEEE Int. Geoscience and Remote Sensing SymposiumIGARSS, pp. 3269-3272.

Aghdasi F. 2010. Crop water requirement assessment and annual planning of water allocation. Univ. of Twente Fac. of GeoInformation and Earth Observation (ITC), pp. 76-79.

Arturo R.G., Jeppe K., Todd T., Christopher H. and Laurent A. 2018. "Estimation of Crop Evapotranspiration Using Satellite Remote Sensing-Based Vegetation Index," Advances in 
Meteorology, Article ID 4525021, 12 p. https://doi.org/10.1155/2018/4525021

Campos I., Neale C.M., Suyker A.E., Arkebauer T.J. and Gonçalves I.Z. 2017. Reflectance based crop coefficients REDUX: for operational evapotranspiration estimates in the age of high producing hybrid varieties. Agric. Water Manag. 187, 140-153.

Daliakopoulos I.N., Panagea I.S., Tsanis I.K., Grillakis M.G., Koutroulis A.G., Hessel R. and Ritsema C.J. 2017. Yield Response of Mediterranean rangelands under a changing climate. Land Degradation \& Development, 28(7), 1962-1972.

https://doi.org/10.1002/ldr.2717

El-Shirbeny M.A., Aboelghar M.A., Arafat S.M. and El-Gindy A.G.M. 2014. Assessment of the mutual impact between climate and vegetation cover using NOAA-AVHRR and Landsat data in Egypt. Arabian J. of Geosciences, 7(4), 1287-1296.

El-Shirbeny, M.A., Ali, A.E.M. and Saleh, N.H. 2014. Crop Water Requirements in Egypt Using Remote Sensing Techniques. J. of Agric. Chem. and Environment, 3, 57-65.

Goetz S., Halthore R., Hall F. and Markham B. 1995. Surface temperature retrieval in a temperate grassland with multiresolution sensors. J. of Geophysical Research: Atmospheres, 100(D12), 25397-25410.

Hasan M., Kassu A. and Mentreddy S.R. 2018. 'Determination of evapotranspiration for cotton in Alabama by the Penman method', Int. J. Hydrology Sci. and Technology, 8(2), 163174.

Justice C.O. and Townshend J.R.G. 2002. Special issue on the Moderate Resolution Imaging Spectroradiometer (MODIS): a new generation of land surface monitoring. Remote Sens. Environ. 83 (1), 1-2.

Kjaersgaard R. Allen and Irmak A. 2011. "Improved methods for estimating monthly and growing season ET using METRIC applied to moderate resolution satellite imagery,". Hydrological Processes, 25(26), 4028-4036.

Mahmoud S.H. and Gan T.Y. 2019. Irrigation water management in arid regions of Middle East: assessing spatio-temporal variation of actual evapotranspiration through remote sensing techniques and meteorological data. Agric. Water Manag 212, 35-47.

Norman J.M., Divakarla M. and Goel N.S. 1995. Algorithms for extracting information from remote thermal-IR observations of the earth's surface. Remote Sensing of Environment, 51(1), 157-168.

Romero-Trigueros P.A. and Nortes J.J. Alarcon 2017 "Efects of saline reclaimed waters and defcit irrigation on Citrus physiology assessed by UAV remote sensing," Agric. Water Management, 183, 60-69.

Rouse J.W., Haas R.H., Schell J.A. and Deering D.W. 1973. "Monitoring vegetation systems in the Great Plains with ERTS," in Tird ERTS symposium, NASA, Washington DC, USA, pp. 309-317.

Rozenstein O., Haymann N., Kaplan G. and Tanny J. 2018. Estimating cotton water consumption using a time series of Sentinel-2 imagery. Agric. Water Manage. 207, 44-52.

Toureiro R. Serralheiro S. Shahidian and Sousa A. 2017. Irrigation management with remote sensing: evaluating irrigation requirement for maize under Mediterranean climate condition," Agric. Water Management, 184, 211-220.

Valor E. and Caselles V. 1996. Mapping land surface emissivity from NDVI: Application to European, African, and South American areas. Remote Sensing of Environment, 57(3), 167184.

Zahid M. and Rasul G. 2011. Thermal classification of Pakistan. Atmos. Climate Sci., 1, 206213. 


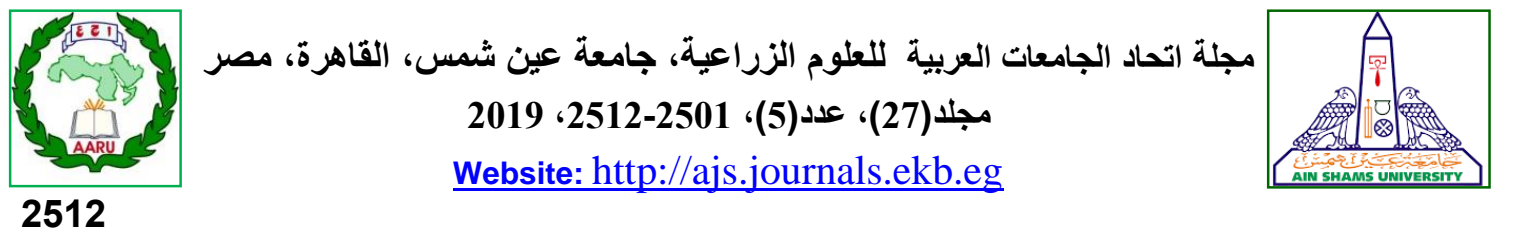

التنبؤ بعيد المدي بالبخر نتح الفعلي للمحاصيل إعتماداً علي تحليل بيانات الأقمار الصناعية

$$
\begin{aligned}
& \text { محمد عبده يوسف1" - ياسر عزت عرفه1" - عبد الغني محمد الجندي1 - محمد أحمد الثربيني2 } \\
& \text { 1- قسم الهندسة الزراعية - كلية الزراعة - جامعة عين شمس- ص.ب } 68 \text { - حدائق شبرا } 11241 \text { - القاهرة - مصر بلئري } \\
& \text { 2- الهيئة القومية للإستشعار عن بعد وعلوم الفضاء - مصر الفراعلئ }
\end{aligned}
$$

*Corresponding author: mohamedabdou25893@gamil.com

Received 2 December, 2019 Accepted 26 December, 2019

كذلك أوضحت نتائج الدراسة أن القيم الصغري

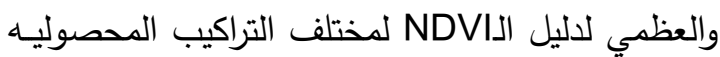

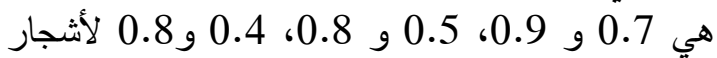
المانجو والزيتون وللغابات الثجرية علي التوالي خلال

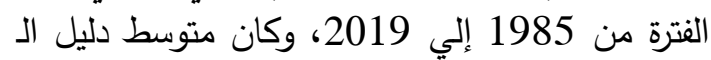
NDVI النتائج أن القيم الصغري والعظمي للبخر نتح الفعلي لتبني تحت مختلف التراكيب المحصوليه هي 2.6 و 4.9

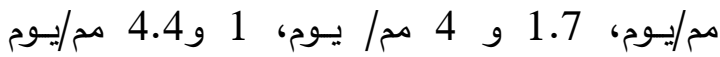
لأشجار المانجو والزيتون وللغابات الثجرية

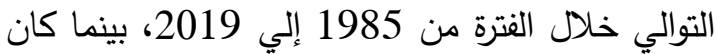

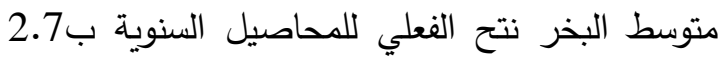
مم/ يوم. خلصت الدراسة إلى أنه يمكن الإستعانة بنتائج هذه الدراسة في تحسين إدارة الري.

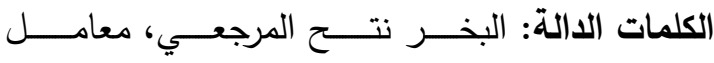

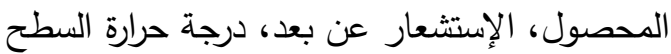<smiles>[AlH2]</smiles>

تعاني المناطق القاحلة من العديد من مشاكل ندرة المياه، ويعزي العديد من هذه المشاكل للتغيرات التيات

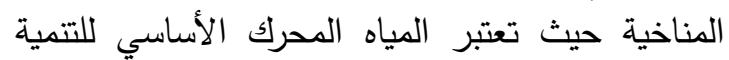
الزراعية تحت ظروف المناطق القاحلة. تهدف الدراسة الداه إلي التتبؤ بالبخر نتح الفعلي تحت مختلف التفاعت التراكيب

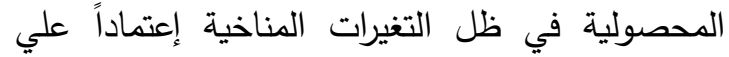

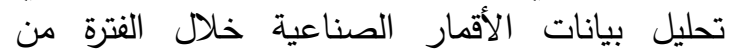
1985 إلي 2019. تم تجميع وتحليل صور الأقمار الصناعية وهي تتمثل في لاندسات 5 ولاندسات 7 ولاندسات 8. أستخدمت هذه البيانات في تقدير البخر نتح المحصولي الفعلي إعتماداً علي دليل التغير في الغطاء النباتي ال NDVI. أوضحت النتائج زيادة كبيرة في الرقعة الزراعية في

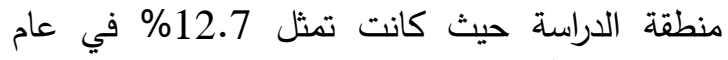
1985 إلي أن وصلت هذه النسبة إلي 64.2\% 2019 من المساحة الأجمالية لمنطقة الدراسة. 